\title{
A DYNAMIC PANEL DATA ANALYSIS FOR RELATIONSHIP BETWEEN TECHNOLOGICAL INNOVATION, ENTREPRENEURSHIP AND ECONOMIC GROWTH

\author{
Tarek Sadraoui ${ }^{\star}$, Anis Ammari ${ }^{\star}$
}

Received date: $* * / * * / 2017$, Accepted date: $* * / * * / 2017$, online publication date: $* * / * * / 2017$

\begin{abstract}
This manuscript aims to study elements of answers to the effect of adequate entrepreneurial activity that would have effects on economic growth. This paper analyzes the relationship between entrepreneurship and economic growth for a dynamic panel data of developing countries over the 2004-2017 periods. We used two measures of entrepreneurship: the new density and the potential of innovation. We estimated a growth function using the method of static and dynamic panel data. Our results show that the new density and growth are significantly and positively correlated. Our results also show that if the short-term impact of technological innovation on growth is negative, this effect is positive in the long term. This result confirms the theoretical predictions, namely the theory of spillage.
\end{abstract}

Keyword: Entrepreneurship; Technological innovation; Economic growth; Dynamic Panel data; causality.

JEL Code: L30 Q55 O47 C33

Citation: $\quad$ SADRAOUI, T., AMMARI, A. (2017). A dynamic panel data analysis for relationship between technological innovation, entrepreneurship and Economic Growth. Journal of Finance and Corporate Governance, Vol., 1, No. 1: pp. 31 - 43. (Jun 2017); ISSN: 2602-5655.

\section{INTRODUCTION}

In today's world where technological change, liberalization, outsourcing, and restructuring rule, the subject of entrepreneurship has gained greater interest. The discussions centered on what actually constitute entrepreneurship and how far it extends. The term entrepreneurship is derived from the French word to undertake.

\footnotetext{
Ł tarek.sadraoui@gmail.com , Mahdia Modelis Lab. Tunisia.

$\star \star$ ammari_anis1@yahoo.fr , Mahdia Modelis Lab. Tunisia.
} 
This suggests that entrepreneurship is the process of undertaking activities concerned with identifying and exploiting business opportunities while assuming its associated risks. Entrepreneurship is about a kind of behavior that includes initiative taking, reorganizing economic activities and the acceptance of its risks (Shapero, 1975). It is important to note that entrepreneurial activities are universal and can therefore be promoted even in societies that manifest low entrepreneurship activities.

Entrepreneurs play a determinant role on the societal, economic and cultural environment of a country. However, they are directly affected by socio-economic, cultural and political environment of a given country as well. By taking into consideration that entrepreneurs are an important influence over a given country's economic success, it is clearly desirable to know what sorts of social institution provide a favorable climate for developing qualities of entrepreneurship (Casson, 1982: 12). Entrepreneurs need a barrier-free business environment to foster an economy.

Business freedom is discussed under economic freedoms in the literature and it is possible to acquire quantitative data on a specific country's business environment where entrepreneurs are active. The economic freedom index to measure this data was created by Heritage Foundation and Wall Street Journal in 1995. There is also another economic freedom index created by Cato Institute, USA and the Fraser Institute, Canada (Lau and Lam, 2002: 664). For the purposes of the study Heritage Foundation and The Wall Street Journal's economic freedom index has been taken into consideration.

The Index is one of the oldest commonly known global indexes. It includes data in 10 freedom categories-business, trade, fiscal, monetary, investment, financial, labor, corruption, government size and property rights, corruption and freedom. The data as far as 1995 is accessible (Acs and Szerb, 2009: 20).

In our paper, we studies firstly, the concepts of entrepreneurship and business freedom have been discussed. Secondly, effects of entrepreneurship and business freedom on economic growth have been put forward. Following the literature review about the past studies in this research area; data, model and econometric methodology have been included in the study. Lastly, findings of the research and concluding remarks have been proposed.

\section{1) Relationship between Entrepreneurship and Economic Development}

The association of entrepreneurship and economic development of nations has long been recognized by economists of the past such as Jean Baptiste (1803) and Joseph Schumpeter (1934). Small firms tend to employ more labour per unit of capital and require less per capital unit of output than do large one (Kuratko and Hodgetts, 1998). Thus, the creation of small businesses and growing the existing ones is considered to be the fastest way to achieve economic growth.

Conventionally, ideas about how businesses ideas emerge in society have assumed that the process starts and ends with the individual character traits (Kilby, 1988). This suggests that an entrepreneurship character is in-born. However, many argue that entrepreneurship behavior could be stimulated through policy intervention (Clelland and Winter, 1969). This is the reason why entrepreneurship is increasingly promoted in less developed countries.

For example, the need for encouraging increased productivity and self-employment has been recognized since 1970s with formulation of the Small Scale Enterprises 
Promotion Policy. Until now, government pronouncements on promoting small enterprises are not always translated into serious policy statements backed by effective implementation mechanisms. In fact, most of the programmes introduced to assist small enterprises only reached a small portion of the total of small business population.

In actual sense, policy makers were more concerned with the establishment of few large enterprises than developing small ones. This was what partly informed the Import Substitution Industry (ISI) Strategy of the late 1970s where huge sum of money was spent on unsustainable mammoth companies. For example, a number of automobile assembly plants were established in various part of the country, many such as Fiat in Kano and Styre in Bauchi states have collapsed. Again, government is unable to improve infrastructure, security and general state of the economy which all have devastating effect on small businesses. Of course, the inability of business owners to change ineffective traditional management practices and adopt innovative reforms also contribute significantly to their misfortune.

Global Entrepreneurship Monitor GEM aims to investigate differences at national levels and types of entrepreneurship and to link these to job creation and economic growth. However, unlike other national economic characteristics, like GDP, or inflation, national entrepreneurship can be referred to as the net result of individual decisions to realize entrepreneurial initiatives. In this individual perspective and in light of the GEM objectives, every person engaged in any behavior related to new business creation, no matter how modest, is relevant to the national level of activity. Total early-stage Entrepreneurial Activity (TEA) is a term that is used to refer to percentage of 18-64 population who are either a nascent entrepreneur or ownermanager of a new business in the GEM studies. Besides, TEA can be divided into two groups based on the gender of entrepreneurs as total early-stage entrepreneurial activity for male working age population and total early-stage entrepreneurial activity for female working age population (GEM, 2013).

Entrepreneurship needs an environment where their activities are not limited. The level of freedom of a business environment can be expressed by the concept of 'business freedom'. Business freedom, a component of economic freedom index, is a quantitative measure of the ability to commence, operate, and end a business in a given country that represents the overall burden of regulation as well as the efficiency of government in the regulatory process (Heritage Foundation, 2011: 447).

\section{3) The impact of entrepreneurship on economic growth}

The theory of economic growth strongly implies the significant role of entrepreneurial activity in the economy (Baumol, 1968: 65). Entrepreneurs in a given economy attempt to shape it by taking available economic activities. Yet, the level to which entrepreneurs enjoy the possible economic opportunities depends on the degree to which entrepreneurs function without restrictions. In order to obtain economic growth a barrier free business environment for entrepreneurs should be designed by the policy makers.

Today entrepreneurship has become increasingly important to developed countries as a source of economic growth and employment creation (Thurik et al., 2008: 673).

Entrepreneurship activities are one of the primary determinants of economic change and the dynamics that move society to a greater economic height. Business start-ups to exploit a perceived business opportunity would lead to economic growth, but it is 
also possible that obligatory entrepreneurship may not lead to economic development. Being pushed into entrepreneurship (self-employment) because all other options for work are either absent or unsatisfactory can even lead to under development (Griffith, 2012: 1). On the contrary, if the existing environment is not suitable for entrepreneurship activities the economy would be affected negatively.

\section{4) A brief literature review}

Among studies that examine the relationship between entrepreneurship and economic growth, studies at the nation-state are limited (Van Stel et al., 2005: 311-321). Barro (1991) showed that entrepreneurs are the most important factors in explaining the differences in growth across economies.

Van Stel (2005) et al. investigated whether TEA influences GDP growth for a sample of 30 countries. They tested whether the influence depended on the level of economic development measured as GDP per capita. The study put forward that entrepreneurial activity by nascent entrepreneurs and owner/managers of young businesses affected economic growth, but that this effect depended upon the level of per capita income. The result suggested that entrepreneurship played a different role in countries in different stages of economic development.

Salgado-Banda (2005) used different two measures as proxy variables of productive entrepreneurship in order to explore the linkage between productive entrepreneurship and economic growth in 22 OECD countries over the period of 1975-1998. These measures are patent applications and self-employment or business ownership. According to Salgado-Banda (2005) entrepreneurship, measured by patent applications, had both statistical and economic relevance on economic growth.

The empirical results showed that self-employment or business ownership appeared to be negatively associated with economic growth. This meant that self-employment could be associated with rent-seeking activities or other non-innovative areas instead of productive entrepreneurship by Salgado-Banda (2005).

Valliere and Peterson (2009) tested the impacts of three types of TEA, namely high expectation entrepreneurship activity (HEA), opportunity entrepreneurial activity (OEA) and necessity entrepreneurial activity (NEA) on GDP growth rates in 24 developed (these countries have per capita GDP more than US\$20.000) and 20 emerging countries (these countries had per capita GDP less than US\$20.000) for years 2004 and 2005.

According to the empirical results of the authors, HEA entrepreneurs seemed to positively contribute growth in the case of developed countries, but other two entrepreneurs did not. The sign of NEA was positive, but NEA was not statistically significant variable. OEAs were negatively associated with growth in developed countries. The case of emerging countries was different to the case of developed countries. Hence, the specific entrepreneurship terms had no significant effects on economic growth.

Vázquez-Rozas et al. (2010) analyzed the effect of entrepreneurial capital on GDP growth in Spanish and Portuguese regions from 2000 to 2008. They used the ratio of companies created in each region as a proxy variable of entrepreneurial capital. They found that the effect of the entrepreneurship capital on GDP growth was positive and significant. 
Klarl (2011) found that entrepreneurial activity positively affected growth rate of ideas on the balanced growth path. Hence, according to Klarl (2011), the existence of lead entrepreneurship contributed significantly to technological change.

\section{5) Model Presentation and econometric methodology of research a) Model presentation}

In order o empirically investigate the impact of entrepreneurship on economic growth, this paper estimate for the available time period, 2004-2015, among 30 countries. In order to overcome the missing data problem, we have taken the mean values of the series because the Ordinary Least Squares estimator we preferred used the deviations from the mean.

The question of which variables determine economic growth has been considered to be one of the most important research questions since Solow's first works in 1950s by many economists. We have focused on the relationship between economic growth and the entrepreneurial activity from entrepreneurship indicators. In this study, the economic growth models which will be estimated are as follows:

$$
\begin{aligned}
& \ln G D P_{i t}=\alpha_{i}+\alpha_{1} B F I_{i t}+\alpha_{2} O T E A_{i t}+\varepsilon_{i t} \\
& \ln G D P_{i t}=\beta_{i}+\beta_{1} B F I_{i t}+\beta_{2} O T E A M_{i t}+u_{i t} \\
& \ln G D P_{i t}=\delta_{i}+\delta_{1} B F I_{i t}+\delta_{2} O T E A F_{i t}+v_{i t}
\end{aligned}
$$

A description of the variables used this study and their data sources follows:

- Member countries' business freedom index (BFI) is taken from the Heritage Foundation (2012).

- GDP per capita based on purchasing power parity (lngdp) is measured by the logarithm of GDP per capita, ppp index $(2005=100)$. The data on GDP are obtained from World Bank's World Development Indicators (2012).

- Total early-stage Entrepreneurial Activity (TEA) is used to measure entrepreneurship. OTEA means the percentage of 18-64 population who are either a nascent entrepreneur or owner-manager of a new business. This data obtained from Global Entrepreneurship Monitor (GEM).

- Total early-stage Entrepreneurial Activity for male working age population (OTEAM) and Total early-stage Entrepreneurial Activity for female working age population (OTEAF) for male and female separately is used as well as OTEA, which is used to measure Entrepreneurial activity. The data on TEA are taken from GEM.

Adding Total early-stage Entrepreneurial Activity for male and female working age population separately to the model and using the recent period have differentiated this study from the other studies subjected the relationship between entrepreneurship and economic growth. In order to estimate these regressions, we preferred the analysis of panel data. The analysis of panel or longitudinal data is the subject of one of the most active and innovative bodies of the economic growth literature, because panel data provide such a rich environment for the development of estimation techniques and theoretical results (Greene, 2008: 54-66).

Table 1 presents the descriptive statistics and correlation matrix of the variables used in the study. According to correlation matrix, all explanatory variables are positively 
correlated with GDP per capita and the intensity of this correlation ranged from twenty one to thirty five percent.

Table 1: Correlation matrix of the variables and descriptive statistics

\begin{tabular}{llllll}
\hline & GDP & OTEA & OTEAM & OTEAF & BFI \\
\hline Mean & 41966.38 & 7.390809 & 8.386727 & 5.291955 & 91.58864 \\
Median & 41840.22 & 5.800000 & 8.600000 & 3.850000 & 95.00000 \\
Maximum & 59155.28 & 36.40000 & 41.80000 & 26.20000 & 100.0000 \\
Minimum & 14213.73 & 0.900000 & 2.300000 & 0.200000 & 76.10000 \\
Std.Dev. & 6509.474 & 4.157619 & 5.026892 & 2.427583 & 8.879218 \\
Correlation Matrix & GDP & OTEA & OTEAM & OTEAF & BFI \\
GDP & 1.000000 & 0.321540 & 0.357388 & 0.127843 & 0.253003 \\
OTEA & 0.321540 & 1.000000 & 0.986548 & 0.970927 & 0.131650 \\
OTEAM & 0.357388 & 0.986548 & 1.000000 & 0.786067 & 0.113498 \\
OTEAF & 0.127843 & 0.970927 & 0.786067 & 1.000000 & 0.267512 \\
BFI & 0.253003 & 0.131650 & 0.113498 & 0.267512 & 1.000000 \\
\hline
\end{tabular}

\section{b) Econometric Methods and Findings}

\section{Panel unit root tests}

In order to get unbiased estimations, firstly we investigate the existence of unit root in the series. Several different panel unit root tests are available. The stationarity properties of the variables are tested by the panel unit root tests of Levin et al. (2002) (LLC), Im et al. (2003) (IPS), and. LLC (2002) assume that the coefficients of lagged dependent variable to be homogenous across all cross sections, while IPS (2003) allow the coefficients of lagged dependent variables to be heterogeneous and for residual serial correlation.

Other test Maddala and Wu (1999) consider deficiency of both the LLC and IPS frameworks and offer an alternative testing strategy (Barbieri, 2006: 5-16). MW is based on a combination of the P-values of the test statistics for a unit root in each cross-sectional unit.

Table 2: Results of Panel Unit Root Test

\begin{tabular}{lllllll}
\hline variable & LLC & \multicolumn{3}{c}{ PP-Fisher } \\
\hline GDP & Constant & Constant & Constant & Constant & Constant & Constant \\
& -2.85 & trend & -0.85 & trend & 31.85 & trend \\
& {$[0.00]^{* * *}$} & 53.13 & {$[0.35]$} & 14.19 & {$[0.00]$} & 10.98 \\
& & {$[1.00]$} & & {$[1.00]$} & & {$[1.00]$} \\
InGDP & -5.32 & -1.97 & -0.78 & -0.91 & -34.52 & -11.91 \\
& {$[0.00]^{* * *}$} & {$[0.02]^{* *}$} & {$[0.15]$} & {$[1.54]$} & {$[0.00]$} & {$[1.02]$} \\
\multirow{2}{*}{ InGDP } & -7.52 & -9.91 & -3.91 & -0.87 & 74.87 & 54.91 \\
& {$[0.00]^{* * *}$} & {$[0.0]^{* * *}$} & {$[0.00]^{* *}$} & {$[0.02]$} & {$[0.00]^{* * *}$} & {$[0.0]^{* * *}$} \\
OTEA & -4.52 & -2.41 & -2.72 & -7.91 & 89.25 & 87.24 \\
& {$[0.00]$} & {$[0.02]^{* * *}$} & {$[0.00]^{*}$} & {$[0.02]^{*}$} & {$[0.00]^{* * *}$} & {$[0.02]^{* * *}$} \\
OTEAM & -12.52 & -6.51 & -11.52 & -9.91 & 129.36 & 114.32 \\
\hline
\end{tabular}


Vol. 1, No. 1 (Jun 2017); ISSN: 2602-5655

\begin{tabular}{lllllll}
\hline \multirow{2}{*}{ OTEAF } & {$[0.00]^{* * *}$} & {$[0.02]^{* * *}$} & {$[0.00]^{* * *}$} & {$[0.02]^{*}$} & {$[0.00]^{* * *}$} & {$[0.00]^{* * *}$} \\
& -5.52 & -3.91 & -4.52 & -1.91 & 145.52 & 163.25 \\
BFI & {$[0.00]^{* * *}$} & {$[0.02]^{* * *}$} & {$[0.00]^{* * *}$} & {$[0.02]^{* *}$} & {$[0.00]^{* * *}$} & {$[0.00]^{* * *}$} \\
& -0.52 & -1.81 & -0.04 & -0.12 & 6.35 & 35.22 \\
InBFI & {$[0.00]$} & {$[0.02]$} & {$[0.14]$} & {$[0.02]$} & {$[0.00]$} & {$[0.02]$} \\
& -0.47 & -0.65 & -0.63 & -0.87 & 45.82 & 41.91 \\
\multirow{2}{*}{$\Delta$ InBFI } & {$[0.00]$} & {$[0.02]$} & {$[0.24]$} & {$[0.42]$} & {$[0.07]^{*}$} & {$[0.09]^{* *}$} \\
& -11.23 & -9.58 & -7.52 & -3.91 & 124.52 & 132.91 \\
& {$[0.00]^{* * *}$} & {$[0.02]^{* * *}$} & {$[0.00]^{* * *}$} & {$[0.02]^{* * *}$} & {$[0.00]^{* * *}$} & {$[0.0]^{* * *}$} \\
\hline
\end{tabular}

Numbers in brackets are p-values. $* * *$ and $* * *$ indicates the statistical significance at 10,5 , and $1 \%$ levels respectively. The max lag lengths were set to 3 and Schwarz Bayesian Criterion was used to determine the optimal lag length.

Results for the panel unit root tests are shown in Table 2. As can be readily seen from Table 2, most of the tests (with the exception of the LLC test) fail to reject the unit root null for GDP and lnGDP in both constant and constant plus time trend, but the tests (with the exception of the IPS test in one case) do reject the null of a unit root for lnGDP in difference form. Similarly we are able to strongly reject the unit root null hypothesis for all indicators of entrepreneurship activity. We are unable to reject the unit root null hypothesis at the 5 percent level significance in all of the tests for BFI, but we are able to reject the null

of a unit root for lnBFI in difference form.

From these findings, we conclude that lnGDP and lnBFI are integrated of order one, or I(1). In addition, all indicators of entrepreneurship activity are integrated of order zero, or I(0). At this stage, it is necessary to turn to panel Cointegration techniques in order to determine whether a long-run equilibrium relationship exists among the nonstationary variables in level form.

\section{Panel Cointegration Tests}

After the order of stationarity has been determined, our next step is to apply panel Cointegration methodology. We perform panel Cointegration tests for three models (lnGDP, lnBFI, OTEA), (lnGDP, lnBFI, OTEAF), and (lnGDP, lnBFI, OTEAM). These tests are developed by Pedroni (1999, 2004). Pedroni (1999) allows for heterogeneous slope coefficients across individuals. This test consists of within dimension and between-dimension, which comprise totally seven component test statistics. To analyze the existence of the long-run equilibrium relationship among the variables, the results of Pedroni panel Cointegration tests we conduct are reported in Table 3 for the three models.

Table 3: Pedroni Panel Cointegration Tests

For first equation

\begin{tabular}{lccc}
\hline & Within-Dimension & \multicolumn{2}{c}{ Between-Dimension } \\
\hline \multirow{3}{*}{ Panel v-stat } & Statistic & Gtatistic \\
& -3.67 & Group rho-Statistic & 6.24 \\
Panel rho-stat & $(0.56)$ & & $(1.00)$ \\
& 4.52 & Group PP-Statistic & 3.52 \\
& $(1.00)$ & & $(0.64)$ \\
\hline
\end{tabular}

OUM EL BOUAGUI UNIVERSITY FACULTY OF ECONOMICS, COMMERCE AND MANAGEMENT SCIENCES 


\begin{tabular}{lccc}
\hline Panel PP-stat & 2.52 & Group ADF-Statistic & 3.45 \\
& $(0.75)$ & & $(0.89)$ \\
Panel ADF-stat & 7.85 & & \\
& $(1.00)$ & & \\
\hline
\end{tabular}

Numbers in parenthesis are p-values. The max lag lengths were set to 4 by Schwarz Bayesian Criterion with the assumption of the deterministic trend and constant.

For second equation

\begin{tabular}{llll}
\hline & Within-Dimension & \multicolumn{2}{c}{ Between-Dimension } \\
\hline \multirow{3}{*}{ Panel v-stat } & Statistic & Group rho-Statistic & 4.32 \\
& -3.65 & & $(1.00)$ \\
Panel rho-stat & $(0.99)$ & Group PP-Statistic & 0.33 \\
& -3.65 & & $(0.49)$ \\
Panel PP-stat & $(0.99)$ & Group ADF-Statistic & -0.00 \\
& 1.82 & & $(0.59)$ \\
Panel ADF-stat & $(0.87)$ & & \\
& 3.62 & & \\
\hline
\end{tabular}

Numbers in parenthesis are p-values. The max lag lengths were set to 4 by Schwarz Bayesian Criterion with the assumption of the deterministic trend and constant.

For third equation

\begin{tabular}{llll}
\hline & Within-Dimension & \multicolumn{2}{c}{ Between-Dimension } \\
\hline \multirow{3}{*}{ Panel v-stat } & Statistic & Group rho-Statistic & 6.12 \\
& -4.65 & & $(1.00)$ \\
Panel rho-stat & $(0.99)$ & Group PP-Statistic & 0.35 \\
& 5.44 & & $(0.69)$ \\
Panel PP-stat & $(0.89)$ & Group ADF-Statistic & -0.00 \\
& 0.84 & & $(0.39)$ \\
Panel ADF-stat & $(0.57)$ & & \\
& 3.98 & & \\
\hline
\end{tabular}

Numbers in parenthesis are p-values. The max lag lengths were set to 4 by Schwarz Bayesian Criterion with the assumption of the deterministic trend and constant.

As it is seen from Table 3, the results of Pedroni panel Cointegration test statistics for the three models strongly fail to reject the null hypothesis of no Cointegration; hence there is no evidence of long-run Cointegration relationships among variables. Thus, we conduct panel OLS estimator in this study.

Table 4: Test of Cross-section Effects

\begin{tabular}{llll}
\hline Effects Test & Statistic Equation & Statistic Equation 2 & Statistic Equation 3 \\
& 1 & & \\
\hline Cross-section F & 276.52 & 271.52 & 286.52 \\
& $(0.00)^{* * *}$ & $(0.00)^{* * *}$ & $(0.00)^{* * *}$ \\
Cross-section Chi-square & 674.45 & 659.78 & 659.96 \\
& $(0.00)^{* * *}$ & $(0.00)^{* * *}$ & $(0.00)^{* * *}$ \\
\hline
\end{tabular}


Numbers in parenthesis are p-values. ${ }^{* * *}$ indicates the statistical significance at 10 level.

Table 4 shows the results of test of cross section fixed effects for the three models. We estimate the relationship among economic growth, business freedom, and entrepreneurship using one-way fixed effects estimator. Employing the one-way fixed effects model will give reliable results since the probability values of both cross section $\mathrm{F}$ and cross-section Chi-square statistics are smaller than 0.01 at significance level.

Table 5: The Results for One-way Fixed Effects Model

For equation 1) Dependent Variable: $\Delta \ln G D P$

\begin{tabular}{lllll}
\hline Panel OLS & $\boldsymbol{\beta}$ & t-ratio & Std.error & Prob. \\
\hline OTEA & 0.0017 & 0.004 & 1.7788 & $0.086^{*}$ \\
$\Delta_{\text {InBFI }}$ & 0.0612 & 0.035 & 1.7896 & $0.081^{*}$ \\
C@trend & 8.8512 & 0.178 & 57.137 & $0.000^{* * *}$ \\
& 0.0078 & 0.002 & 6.8570 & $0.000^{* * *}$ \\
\hline$* * *$ and *** & indicates the & statistical significance at level $10 \%, 5 \%$ and $1 \%$ \\
respectively.
\end{tabular}

For equation 2) Dependent Variable: $\Delta \ln G D P$

\begin{tabular}{lllll}
\hline Panel OLS & $\boldsymbol{\beta}$ & t-ratio & Std.error & Prob. \\
\hline OTEAM & 0.0017 & 0.002 & 1.8000 & $0.296 *$ \\
$\Delta_{\text {InBFI }}$ & 0.0675 & 0.052 & 1.8796 & $0.087^{*}$ \\
C@trend & 10.8622 & 0.171 & 59.138 & $0.000 * * *$ \\
& 0.0059 & 0.001 & 6.3000 & $0.000 * * *$ \\
\hline$* * *$ and *** & indicates the & statistical significance at level $10 \%, 5 \%$ and $1 \%$ \\
respectively. & &
\end{tabular}

For equation 3) Dependent Variable: ${ }^{\Delta} \ln G D P$

\begin{tabular}{lllll}
\hline Panel OLS & $\boldsymbol{\beta}$ & t-ratio & Std.error & Prob. \\
\hline OTEAF & 0.0041 & 0.002 & 1.7854 & $0.0752^{*}$ \\
$\Delta_{\mathrm{InBFI}}$ & 0.0726 & 0.042 & 1.3546 & $0.086 *$ \\
C@trend & 9.7854 & 0.180 & 59.154 & $0.000 * * *$ \\
& 0.0089 & 0.001 & 6.5873 & $0.000 * * *$ \\
\hline$* * *$ and $* * *$ indicates the statistical significance at level $10 \%, 5 \%$ and $1 \%$
\end{tabular}

respectively.

The results obtained from the one-way fixed effects are shown in table 5. According to Table 5, business freedom index has statistically significant and positively effect on economic growth for all three models as expected from the literature.

Interestingly, even though OTEAM has no significantly impact on economic growth, the both the coefficients of OTEA and OTEAF, which are used as the indicators of entrepreneurial activity are significant and positive in all three models. Hence, we can say that business freedom and especially Total early-stage Entrepreneurial Activity 
for female working age population are important determinants in promoting economic growth.

\section{6) Conclusion}

This paper contributes to the empirical literature on the determinants of economic growth across countries. In this study, the relationship among business freedom, entrepreneurship and economic growth nexus in selected 30 countries over the period 2004-2015 was surveyed. After reviewing the theoretical principles and experimental studies, the model and estimation was introduced.

The empirical part of the paper uses data on business freedom and Total early-stage Entrepreneurial Activity for male and female working age population separately as a measure of entrepreneurship from a database including 30 countries covering the period 2004 to 2015.

We also hope our findings will be of interest to public policy makers.

Adding Total early-stage Entrepreneurial Activity for male and female working age population separately to the model and using the recent period have differentiated this study from the other studies subjected the relationship between entrepreneurship and economic growth. In order to estimate these regressions, we preferred the analysis of panel data.

Women's entrepreneurship has been recognized during the last decade as an important untapped source of economic growth and the studies with the topic of women in entrepreneurship has been largely neglected in the social sciences. However, a number of women who are involved in businesses have increased. In addition The World Bank's World Development Report 2011 suggests that productivity could increase by as much as $25 \%$ in some countries if discriminatory barriers against women were removed. Removing these barriers, such as discriminatory property and inheritance laws, cultural practices, lack of access to formal financial institutions, and time constraints due to family and household responsibilities, will create greater opportunities for sustainable enterprises run by women.

This in turn will contribute to women's economic empowerment and gender equality as well as helping to generate sustainable growth and jobs (ILO, 2012). From this point of view, we focused on women's entrepreneurship in addition to total entrepreneurship.

According to the obtained empirical findings, business freedom index has statistically significant and positively effect on economic growth for all three models as expected from the literature. Interestingly, even though OTEAM has no significantly impact on economic growth, the both the coefficients of OTEA and OTEAF, which are used as the measurements of entrepreneurship are significant and positive in all three models. Hence, we can say that business freedom and Total early-stage Entrepreneurial Activity for female working age population are important determinants in promoting economic growth.

Consequently female entrepreneurship contributes to countries' economic growth using unique skills, resources and practices. In particular, there is a high correlation of economic growth and entrepreneurial activity among countries 


\section{References}

Acs, Zoltan \& Szerb, Laszlo. (2009). The Global Entrepreneurship Index (GEINDEX), Foundations and Trends in Entrepreneurship. USA: Now Publishers.

Barbieri, L. (2006). Panel Unit Root Tests: A Review. Quaderni Del Dipartimento Di Scienze Economiche E Sociali, Università Cattolica Del Sacro Cuore, N.43: 153.

Barro, R.J. (1991). Economic Growth in a Cross Section of Countries. The Quarterly Journal of Economics, Vol.106, No.2, 407-443.

Baumol, William J. (1968). Entrepreneurship in Economic Theory. The American Economic Review, Vol. 58, No. 2, Papers and Proceedings of the Eightieth Annual Meeting of the American Economic Association, May, 64-71.

Braunerhjelm, P. (2010). Entrepreneurship, Innovation and Economic Growth - Past Experience Current Knowledge and Policy Implications. CESIS Electronic Working Paper Series, No:224, 1-82.

Casson, Mark. (1982). The Entrepreneur, An Economic Theory. USA: Barnes \& Noble Books.

GEM. Consortium, Key Indicators and Definitions. http://www.gemconsortium.org/docs/ download/414, Date of Access: April 6th, 2013.

GEM. GEM. http://www.gemconsortium.org/.

Greene, W. H. (2008). Econometric Analysis. NJ: Prentice-Hall: Englewood Cliffs.

Griffith, Larry. (2012). Absorption of the Successful Entrepreneur: Challenges and Complexities Leading to Further Achievement. Proceedings of the International Conference on Engaged Management Scholarship, 1-21.

Heritage Foundation. (2011). 2011 Index of Economic Freedom. The USA.

Heritage Foundation. http://www.heritage.org/, Date of Access: July 15th, 2012.

ILO. International Labour Office, Women's Entrepreneurship Development, Sustainable Enterprise Programme, 10th Anniversary, 2012.

Im, Kyung So, Pesaran, M. Hashem \& Shin, Yongcheol. (2003). Testing for Unit Roots in Heterogeneous Panels. Journal of Econometrics, 115: 53-74.

Klarl, T. (2011). A Spatially-related Note on Entrepreneurship and Economic Growth. University of Augsburg, Beitrag Nr. 317, 1-22.

Lau, K-N \& Lam, P-Y. (2002). Economic Freedom Ranking of 161 Countries in Year 2000:

A Minumum Disagreement Approach. Journal of the Operational Research Society, No:53, 664-671.

Levin, Andrew, Lin, Chien-Fu \& James Chu, Chia-Shang. (2002). Unit Root Tests in Panel Data: Asymptotic and Finite-Sample Properties. Journal of Econometric, 108: 1-24.

Maddala, G. S. \& Wu, Shaowen. (1999). A Comparative Study of Unit Root Tests with Panel Data and a New Simple Test. Oxford Bulletin of Economics and Statistics, Special Issue, 0305-9049: 631-652.

Nyström, Kristina. (2008). The Institutions of Economic Freedom And Entrepreneurship: Evidence From Panel Data. Public Choice, Springer 136, No:3, 269-282.

Pedroni, Peter. (1999). Critical Values For Cointegration Tests In Heterogeneous Panels With 
Multiple Regressors. Oxford Bulletin of Economics and Statistics, 61: 653-670.

Pedroni, Peter. (2004). Panel Cointegration: Asymptotic and Finite Sample Properties of Pooled Time Series Tests with an Application To the Ppp Hypothesis. Econometric

Theory, 20(3): 597-625.

Reynolds, Paul, Bomsa, Niels, Autio, Erkko, Hunt, Steve, De Bono, Natalie, Servais, Isabel, Lopez-Garcia, Paloma \& Chin, Nancy. (2005). Global Entrepreneurship Monitor:

Data Collection Design and Implementation 1998-2003. Small Business Economics, 24, Springer, 205-231.

Salgado-Banda, Héctor. (2005). Entrepreneurship and Economic growth: An Empirical Analysis. Working Paper, Banco de México, 1-46.

Thurik, Roy, Carre, Martin A., Stel, Andre Van \& Audretsch, David B. (2008). Does Self-Employment Reduce Unemployment?. Journal of Business Venturing 23, 673-686.

Valliere, Dave \& Peterson, Rein. (2009). Entrepreneurship and Economic Growth: Evidence From Emerging and Developed Countries. Entrepreneurship \& Regional Development 21, No.5-6, 459-480.

Van Stel, Andre, Carree, Martin \& Thurik, Roy. (2005). The Effect of Entrepreneurial Activity on National Economic Growth. Small Business Economics, 24, Springer, 311-321.

Vázquez-Rozas, Emilia E., Gómes, Sofía \& Vieira, Elvira. (2010). Entrepreneurship and Economic Growth in Spanish and Portuguese Regions. Regional and Sectoral Economics Studies 10, No.2, 109-126.

Wennekers, Sander \& Thurik, Roy. (1999). Linking Entrepreneurship and Economic Growth.

Small Business Economics, 13, 27-55.

Wong, Poh Kam, Ho, Yuen Ping \& Autio, Erkko. (2005). Entrepreneurship, Innovation and Economic Growth: Evidence from GEM Data. Small Business Economics 24, 335-350.

World Bank. http://www.worldbank.org.

Mowery, David C. and Rosenberg, Nathan, 1998. Paths of Innovation: Technological Change in 20th-Century America. Cambridge: Cambridge University Press.

Mowery, David C. and Sampat, Bhaven N., 2001a. "Patenting and Licensing University Inventions: Lessons from the History of the Research Corporation." Industrial and Corporate Change, 10 (2), 317-355.

Mowery, David C. and Sampat, Bhaven N., 2001b. "University Patents and Patent Policy Debates in the USA, 1925-1980." Industrial and Corporate Change, 10 (3), 781-814.

Nelson, Richard R. and Wright, Gavin, 1992. "The Rise and Fall of American Technological Leadership: The Postwar Era in Historical Perspective," Journal of Economic Literature, 30 (4), 1931-1964.

Noble, David, 1977. America by Design. Oxford: Oxford University Press.

NSF (National Science Foundation), Division of Science Resources Statistics, 2006a. Academic Research and Development Expenditures: Fiscal Year 2004. NSF 06323. Arlington, VA: NSF.

NSF (National Science Foundation), Division of Science Resources Statistics, 2006b. National Patterns of R\&D Resources: 2004 Date Update, NSF 06-327. Arlington, VA: NSF. 
OECD (Organization of Economic Cooperation and Development), 2002. Frascati Manual. Proposed Standard Practice for Surveys on Research and Experimental Development. Paris: OECD.

Phelps, Edmund S., 2006. "Understanding the Great Changes in the World: Gaining Ground and Losing Ground since World War II. Capitalism and Society, 1 (2), p. 1010.

Ritter, Jay R., 2006. "Some Factoids About the 2005 IPO Market." http://bear.cba.ufl.edu/ritter.

Roberts, Edward B., 1991. Entrepreneurs in High Technology: Lessons from MIT and Beyond. Oxford: Oxford University Press.

Romer, Paul, 1986. "Increasing Returns and Economic Growth," American Economic Review, 94, 1002-1037.

Romer, Paul, 1990. "Endogenous Technical Change," Journal of Political Economy, 98, 71-102.

Rosenberg, Nathan, 1985. "The Commercial Exploitation of Science by American Industry," in Kim B. Clark, Robert H. Hayes and Christopher Lorenz (eds.), The Uneasy Alliance: Managing the Productivity-Technology Dilemma. Boston, MA: Harvard Business School Press, 19-51.

Rosenberg, Nathan, 1992. "Scientific Instrumentation and University Research," Research Policy, 21 (3), 381-390.

Rosenberg, Nathan, 1998. "Technological Change in Chemicals: The Role of University-Industry Relations," in A. Arora, R. Landau and N. Rosenberg (eds.), Chemicals and Long-Term Economic Growth: Insights from the Chemical Industry. New York: Wiley, 193-230.

Rosenberg, Nathan, 2000. Schumpeter and the Endogeneity of Technology. Some American Perspectives. New York: Routledge.

Rosenberg, Nathan and Nelson, Richard R., 1994. "American Universities and Technical Advance in Industry," Research Policy, 23 (3), 323-348.

Scherer, Frederic M. , 1996. Industry Structure, Strategy, and Public Policy. New York: HarperCollins College Publishers.

Shane, Scott, 2004. Academic Entrepreneurship: University Spinoffs and Wealth Creation. Cheltenham, UK: Edward Elgar.

Snyder, Thomas D., 1993. 120 Years of American Education: A Statistical Portrait. Center for Education Statistics, http://nces.ed.gov/pubs93/93442.pdf

Thursby, Jerry G. and Thursby, Marie C., 2002. "Who Is Selling the Ivory Tower? S 